\title{
IMPACT OF FARMYARD MANURE ON THE AVAILABILITY OF SOME HEAVY METALS IN FLOODED RICE SOILS IRRIGATED WITH DRAINAGE WATER
}

Hammad, S. A.*; S. A. Ghanem ${ }^{\star \star}$; E. S. Naeem ${ }^{\star \star}$ and Howida B. El-habet **

* Soil Sci. Dept. of Agric., Mansoura Univ., Egypt.

${ }^{\star *}$ Rice Research and training Center Sakha, Kafr EL-Sheikh

\begin{abstract}
A field experiment was conducted in summer season 2007 at the farm of Rice Research and Training Center farm Kafr El-Sheikh to study the impact of FYM and urea and their combination with using drainage water for irrigation on availability of some heavy metals such as Lead(Pb), nickel (Ni), Cadmium (Cd). Results indicated that the highest values of available $\mathrm{pb}^{+2}, \mathrm{Ni}^{+2}, \mathrm{Cd}^{+2}$ were found with the combination of $150 \mathrm{~kg}$ urea plus the rate of 9 ton FYM. Fed ${ }^{-1}$. Data indicated that the lowest values of available $\mathrm{Cd}^{2+}, \mathrm{Ni}^{2+}$ and $\mathrm{pb}^{2+}$ in soil were found at flowering stage compared with the other stages at all treatments. The results of simple correlation coefficient $(r)$ between organic matter ( OM) ( $\mathrm{y}$ ) and each of available $\mathrm{Pb}^{+2}\left(\mathrm{X}_{1}\right)$, available $\mathrm{Ni}^{+2}\left(\mathrm{X}_{2}\right)$ and available $\mathrm{Cd}^{+2}\left(X_{3}\right)$ at harvest stages showed the character most closely associated with organic matter was the available $\mathrm{Pb}^{+2}\left(X_{1}\right)(R=0.9)$. Multiple linear regressions showed that the prediction equation for organic matter was formulated as follows: $Y=-0.8+0.224 X_{1}+0.301 X_{2}+2.62 X_{3}$
\end{abstract}

\section{INTRODUCTION}

In arid and semi arid regions where water is most scarce and soil fertility is low, the concept of irrigation with poor quality water is becoming more important. So, Egypt started to look for drainage water reuse for irrigation in order to, cover the shortage of fresh water and meet their demands for more food production such, water may added heavy metals to the soil.

In some areas, this water is polluted by the sewage effluents which are damped into the agriculture drainage system. In north delta region, soils irrigated by drainage water polluted by waste water effluent of some factories were higher in heavy metals content than the normal soil (Zein et al 1998).

Increasing levels of heavy metals in soil irrigated with sewage sludge are considered to cause potentially serious hazards in the soil, plant and animal system ( Aboulroos et al 1991).

The mobility of heavy metals in soils differs according to the soil condition, soil $\mathrm{pH}$, type of element and organic matter content are the most important soil components affecting heavy metals movement and accumulation.

Organic materials such as crop residues, FYM and rice straw are available in abundance and reach tremendous amount day after day. Obviously, this means the loss of a great proportion of the organic matter needed to be composed to keep soil productivity. On the other hand, organic matter plays an important factor in the mobility of heavy metals in soil. 
Organic matter contains many functional groups which sequestrate and chelate many trace elements such reactions affect the equilibrium of elements in the soil and consequently the plant uptake of these elements by plants.

\section{MATERIALS AND METHODS}

A field experiment was conducted at the Rice Research and Training Center Farm using Giza 178 rice variety (Oryza sativa L.) to achieve the study objectives. The experiment was conducted in clayey soil , some of its physical and chemical characteristics were determined according to the standard procedures as described by Cottenie et al., (1982) and Page et al., (1982) (Table 1).

Table 1: Some mechanical and chemical analyses of soil used

\begin{tabular}{|c|c|}
\hline \multirow{2}{*}{\multicolumn{2}{|c|}{$\begin{array}{c}\text { Tested characteristics } \\
\text { Piratical size distribution }\end{array}$}} \\
\hline & \\
\hline Sand $\%$ & 27.3 \\
\hline Silt $\%$ & 28.64 \\
\hline Clay $\%$ & 44.06 \\
\hline Texture class & Clayey \\
\hline PH (1:2.5 soil water suspension) & 8.10 \\
\hline $\mathrm{EC}$ ( soil paste extracted at $\left.25 \mathrm{c}^{0} \mathrm{dS} . \mathrm{m}^{-1}\right)$ & 3.00 \\
\hline OM ( organic matter ) \% & \\
\hline Total carbonate \% & 1.65 \\
\hline Soluble cations, meq. $\mathrm{I}^{-1}$ ( soil paste ): & \\
\hline $\mathrm{Ca}^{++}$ & 9.5 \\
\hline $\mathrm{Mg}^{++}$ & 3.94 \\
\hline $\mathrm{K}^{+}$ & 1.76 \\
\hline $\mathrm{Na}^{+}$ & 14.8 \\
\hline $\begin{array}{l}\text { Soluble anoins, meq. } .^{-1} \text { (soil paste ): } \\
\mathrm{CO}_{3}^{--}\end{array}$ & - \\
\hline $\mathrm{HCO}_{3}^{--}$ & 6.00 \\
\hline $\mathrm{Cl}^{-}$ & 8.30 \\
\hline $\begin{array}{l}\mathrm{SO}_{4}^{-} \\
\text {Available heavy metals. }\end{array}$ & 15.7 \\
\hline Available heavy metals: & \\
\hline $\mathrm{Pb}$ & 1.60 \\
\hline $\mathrm{ppm}$ & 0.015 \\
\hline
\end{tabular}

The randomized complete block design with four replications was used, involving 12 treatments derived from $3 \mathrm{~N}$ - fertilizer $(0,46$ and $69 \mathrm{Kg} \mathrm{N}$. $\mathrm{fed}^{-1}$ ) combined with Farmyard manure at the rate of $0,3,6$ and 9 ton FYM .fed $^{-1}$. FYM was added before transplanting. Urea was added in two splits, $2 / 3$ before transplanting and the other $1 / 3$ one month after transplanting.

The obtained date of the organic matter, available $\mathrm{pb}^{+2}$, available $\mathrm{Ni}^{+2}$ and available $\mathrm{Cd}^{+2}$ were subjected to simple correlation and regression. The 
same data were also subjected to multiple linear regressions and stepwise according to this formula:

$$
Y=a+b_{1} x_{1}+b_{2} x_{2}+b_{3} x_{3} \text { according to Hammad, (1995). }
$$

\section{RESULTS AND DISCUSSION}

\section{Heavy metals availability in soil}

\section{1- lead $(\mathrm{Pb})$ availability:}

Table 2 Show the available $\mathrm{Pb}$ in soil treated with farm yard manure (FYM) and urea treatment and their combination at different stages of rice growth. Data illustrated that available $\mathrm{Pb}$ increased with increasing levels of FYM added to the soil either, alone or in combinations with urea at all stages compared with the control. These results are in accordance with those obtained by Kandil Hala (2005). Results also, indicated that the highest values of available $\mathrm{Pb}(4.31,5.85,5.09$ and $5.35 \mathrm{ppm})$ were recorded with combinations with urea at $150 \mathrm{~kg}$. fed $^{-1}$ plus the rate of 9 tons FYM.fed $^{-1}$ treatment at maximum tillering, panicle initiation, flowering and at harvest, respectively. These results are in harmony with those obtained by Huang et al.,(1995)

Data in the same table showed that the available $\mathrm{Pb}$ increased at all treatments with time till panicle initiation then tended to decrease at later stages of rice growth (flowering and at harvest). This finding and conclusion are in agreement with the results obtained by (Yanni ,1979) who observed the large amount of $\mathrm{CO}_{2}$ formed under anaerobic conditions due to the decomposition of starch might have converted some insoluble heavy metals to more soluble. Data indicated also, that lowest values of available $\mathrm{Pb}$ in soil were found at flowering stage compared with the other stages at all treatments. This could be attributed to $\mathrm{Pb}$ organic complexes which are rather stable (Kabata- Pendias and Pendias, 2000).

Table 2: Effect of farmyard manure (FYM) and different rates of urea and their combination on available lead $(\mathrm{Pb})$ at different stages of rice growth (ppm).

\begin{tabular}{|c|c|c|c|c|c|c|}
\hline Treatments & $\begin{array}{c}\text { Urea } \\
\text { kg. fed } \text { fed }^{-1}\end{array}$ & $\begin{array}{c}\text { FYM } \\
\text { t. } \text { fed }^{-1}\end{array}$ & $\begin{array}{l}\text { Maximum } \\
\text { tillering }\end{array}$ & $\begin{array}{c}\text { Panicle } \\
\text { initiation }\end{array}$ & Flowering & Harvest \\
\hline NOF0 & 0 & 0 & 3.57 & 4.79 & 4.08 & 4.31 \\
\hline NoF1 & 0 & 3 & 3.72 & 4.93 & 4.38 & 4.52 \\
\hline NoF2 & 0 & 6 & 3.88 & 5.17 & 4.62 & 4.85 \\
\hline N0F3 & 0 & 9 & 3.97 & 5.32 & 4.83 & 5.02 \\
\hline N1F0 & 100 & 0 & 3.53 & 4.76 & 4.33 & 4.57 \\
\hline N1F1 & 100 & 3 & 3.82 & 5.16 & 4.59 & 4.75 \\
\hline N1F2 & 100 & 6 & 3.92 & 5.42 & 4.77 & 4.91 \\
\hline N1F3 & 100 & 9 & 4.03 & 5.74 & 4.92 & 5.20 \\
\hline N2F0 & 150 & 0 & 3.68 & 4.83 & 4.42 & 4.65 \\
\hline $\mathrm{N} 2 \mathrm{~F} 1$ & 150 & 3 & 3.94 & 5.38 & 4.73 & 4.86 \\
\hline N2F2 & 150 & 6 & 4.15 & 5.56 & 4.88 & 5.01 \\
\hline N2F3 & 150 & 9 & 4.31 & 5.85 & 5.09 & 5.35 \\
\hline
\end{tabular}


2-Nickel (Ni) availability:

Table 3 shows the available $\mathrm{Ni}$ in soil treated with FYM and urea treatment and their combinations at different stages of rice growth.

Data revealed that at all stages of rice growth (maximum tillering, panicle initiation, flowering and at harvest) available $\mathrm{Ni}$ in soil increased with increasing the levels of FYM, whether, added to the soil alone or in combinations with urea compared to the control. These results are in accordance with those obtained by Kabata - Pendias and Pendias (2000) who found that reaction between organic matter and $\mathrm{Ni}$ which led to the solubility of humic acid complexes with $\mathrm{Ni}$ at high $\mathrm{pH}(7$ to 9.3) and precipitation at low $\mathrm{pH}$.

Data also, indicated that the highest values of available $\mathrm{Ni}(4.62,3.23$, 3.01 and 3.90) were attained with combinations of urea at $150 \mathrm{~kg}$ urea plus the rate of 9 tons FYM.fed $^{-1}$ treatment at maximum tillering, panicle initiation, flowering and at harvest respectively. These results are in harmony with those obtained by Stevenson (1995) who observed that organic complexes agents act as carriers of trace elements in the soil solution, thereby enhancing the availability of trace elements to plant, as well as to soil micro organisms.

Data in the same Table showed that available $\mathrm{Ni}$ decreased with progress stages of rice growth. This could be attributed to 1) The absorption of $\mathrm{Ni}$ by plant. 2) Sulphate ions which reduced to sulphides under flooded conditions and this can lead to the precipitation of metal sulphides such as $\mathrm{PbS}, \mathrm{NiS}$ and CdS. 3) Metal ion concentrations levels in the soil solutions may be reduced to nontoxic through complex with organic matter. This is particularly true when the metal organic complexes has low solubility such as in the case of complexes with humic acids and other high molecular weight components of organic matter (Abou Seeda etal,1997). Data clearly show that the highest values of available Ni were found at maximum tillering stage at all treatments and then decreased with other stages ( panicle initiation, flowering and at harvest).

Table (3): Effect of farm yard manure (FYM) and different rates and their combination of urea on available nickel ( $\mathrm{Ni}$ ) at different stages of rice growth (ppm).

\begin{tabular}{|c|c|c|c|c|c|c|}
\hline Treatments & $\begin{array}{c}\text { Urea } \\
\text { Kg. fed }_{\mathbf{1}}\end{array}$ & $\begin{array}{c}\text { FYM } \\
\text { t. fed }^{-1}\end{array}$ & $\begin{array}{c}\text { Maximum } \\
\text { tillering }\end{array}$ & $\begin{array}{c}\text { Panicle } \\
\text { initiation }\end{array}$ & Flowering & Harvest \\
\hline N0F0 & 0 & 0 & 3.52 & 2.01 & 1.91 & 2.84 \\
N0F1 & 0 & 3 & 3.79 & 2.21 & 2.28 & 3.02 \\
N0F2 & 0 & 6 & 3.95 & 2.52 & 2.39 & 3.29 \\
N0F3 & 0 & 9 & 4.13 & 2.86 & 2.65 & 3.40 \\
N1F0 & 100 & 0 & 3.84 & 2.09 & 1.94 & 2.83 \\
N1F1 & 100 & 3 & 4.04 & 2.49 & 2.39 & 3.20 \\
N1F2 & 100 & 6 & 4.25 & 2.89 & 2.69 & 3.50 \\
N1F3 & 100 & 9 & 4.53 & 3.08 & 2.91 & 3.70 \\
N2F0 & 150 & 0 & 4.02 & 2.14 & 2.09 & 3.16 \\
N2F1 & 150 & 3 & 4.27 & 2.81 & 2.67 & 3.36 \\
N2F2 & 150 & 6 & 4.45 & 2.23 & 2.91 & 3.72 \\
N2F3 & 150 & 9 & 4.62 & 2.23 & 3.01 & 3.90 \\
\hline
\end{tabular}




\section{2- Cadmium (Cd) availability:}

Available cadmium (Cd) in soil (ppm) as affected by the applications of farm yard manure (FYM) and urea treatments and their integration at different stages are presented in Table (4). Data revealed that at all stages of rice growth, available Cd in soil increased with increasing levels of FYM added to the soil either separated or in combinations with urea compared with the control. These might be first, due to as alkalinity increases $\mathrm{Cd}$ adsorbtion decreases. Probably due to the competition from $\mathrm{Ca}^{+2}$ and $\mathrm{Mg}^{+2}$ ions. Second, complexing and chelation of $\mathrm{Cd}$ with organic ligands led to solubilities of humic acid complexes with $\mathrm{Cd}$. Third, the soil $\mathrm{pH}$ values under flooded soil tend to neutrality. Fourth, in alkaline soil, monovalent hydroxy ion species are likely to occur $\left(\mathrm{CdOH}^{+}\right)$, which not easily occupy the sites on cationic exchange capacity. These results are in quite agreement with those reported by Kabata- pendias and pendias (2000).

Concerning to changes of available $\mathrm{Cd}$ in soil through different stages of rice growth. Data in the same Table illustrated that the available $\mathrm{Cd}^{2+}$ increased at all treatments with lapse of time at maximum tillering and panicle initiation but their trended to decrease at later stages of rice growth (flowering and at harvest). This increase of available $\mathrm{Cd}^{2+}$ during maximum tillering and panicle Initiation may be due to organic acids release as a result of organic matter fermentation caused decrease of soil $\mathrm{pH}$. These results are in harmony with those obtained by (Yanni 1979).

It is clear from the data the lowest values of available $\mathrm{Cd}^{2+}$ in soil were attained at flowering stage compared with the other stages at all treatments. It may be attributed to 1) Increase head of water over surface soil, with progress height of rice plant, which increases anaerobic conditions that caused a reduction of sulphate ions to sulphides which form a complex with $\mathrm{Cd}^{2+}$ and $\mathrm{Ni}$ and immobilize them as sulphide salts 2) Humic materials in anaerobic system are usually characterized by large molecular weight and greater structural complexity, caused increase metal retention capacity (Chen and Avnimelech 2002).

Table (4): Effect of farmyard manure (FYM) and different rates of urea and their combination on available cadmium (ppm) at different stages of rice growth.

\begin{tabular}{|c|c|c|c|c|c|c|}
\hline Treatments & $\begin{array}{c}\text { Urea } \\
\text { Kg. fed }^{-1}\end{array}$ & $\begin{array}{c}\text { FYM } \\
\text { t. fed }^{-1}\end{array}$ & $\begin{array}{c}\text { Maximum } \\
\text { tillering }\end{array}$ & $\begin{array}{c}\text { Panicle } \\
\text { initiation }\end{array}$ & Flowering & Harvest \\
\hline N0F0 & 0 & 0 & 0.192 & 0.194 & 0.178 & 0.180 \\
N0F1 & 0 & 3 & 0.259 & 0.274 & 0.201 & 0.185 \\
N0F2 & 0 & 6 & 0.275 & 0.293 & 0.208 & 0.213 \\
N0F3 & 0 & 9 & 0.287 & 0.296 & 0.224 & 0.268 \\
N1F0 & 100 & 0 & 0.225 & 0.239 & 0.185 & 0.164 \\
N1F1 & 100 & 3 & 0.271 & 0.282 & 0.212 & 0.213 \\
N1F2 & 100 & 6 & 0.283 & 0.293 & 0.222 & 0.238 \\
N1F3 & 100 & 9 & 0.295 & 0.306 & 0.239 & 0.274 \\
& & & & & & \\
N2F0 & 150 & 0 & 0.225 & 0.234 & 0.189 & 0.174 \\
N2F1 & 150 & 3 & 0.281 & 0.276 & 0.218 & 0.213 \\
N2F2 & 150 & 6 & 0.297 & 0.308 & 0.233 & 0.249 \\
N2F3 & 150 & 9 & 0.313 & 0.314 & 0.248 & 0.280 \\
\hline
\end{tabular}


Simple correlation coefficient $(r)$ between organic matter ( OM) $(y)$ and each of available $\mathrm{Pb}^{2+}\left(X_{1}\right)$, available $\mathrm{Ni}^{2+}\left(\mathrm{X}_{2}\right)$ and available $\mathrm{Cd}^{2+}\left(\mathrm{X}_{3}\right)$ at harvest stages indicated that the character most closely associated with organic matter was the available $\mathrm{Pb}^{2+}\left(\mathrm{X}_{1}\right)$. The simple correlation coefficient between $y$ and $x$ was 0.9 . The simple regression equation for predicting organic matter was computed from the following equation

\section{$Y=-6.43223+2.60501 X-0.181143 X^{\star \star 2}$ with}

\section{$\mathrm{R}-\mathrm{Sq}=\mathbf{8 2 . 8 \%}$ (fig. 1 )}

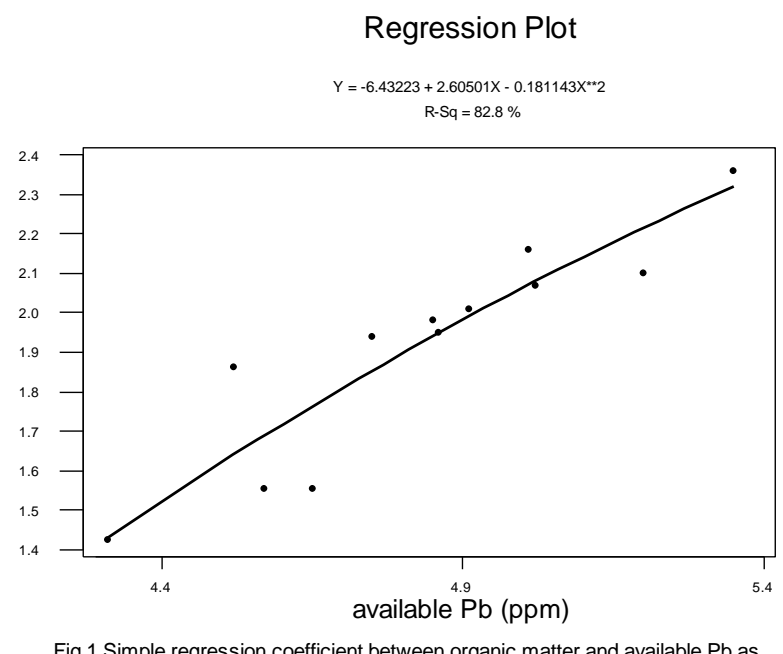

affected by different treatments in 2007 season.

\section{REFERENCES}

Aboulroos, S.A., Sh. Sh. Hola, El Kkerbay and S.H.Badaway.1991. Fractionation of some heavy metals in soil irrigated with sewage effluent for different years. Egypt. J. Soil Sci., 31(1), 43.

Abou Seeda, M; S. Soliman and A. Khatar 1997. Cu, Zn and Cd contents in rice plants and their fractions in soil- amended with sewage sludg controlled PH and redox potential. Egypt. D. Soil. 37(1): 61-79.

Cottenie, A. M. Verloo; L. Kiekens, G. Velghe and R. Camerlynch. (1982). Chemical Analysis of Plants and Soils. Laboratory of Analytical and Agro. Chemistry state University, Ghent. Belgium.

Chen, Y. and Y. Avnimelech 2002. The role of orgnic matter in modern agriculture. CRC. Press, Inc united states and Canada, 631086 C.R

Hammad, S.A. (1995).Pollution of leached water and some nutrients availability as a parameter of efficiency of biological and inorganic $\mathrm{N}$ sources under submergence conditions. J. Agric . Sci. Mansoura univ.20(4)1915-1931.

Huang, P. M. D. Berthelin, D.M. Bollag, W. B. McGill and A.L Page. 1995. Environmental Impact of soil component interactions. CRC. Press, Inc. Boca Raton London, Tokyo. 
Kabata- Pendias, A. and H. Pendisa 2000. Trace Elements in Soils and Plants. Crs press, inc. Boca Raton London New York Washington, D.c.

Kandil Hala, A.H.2005. Impact of agricultural wastes compost on some heavy metals content in soil and plant. Ph.D. Thesis Fac of Agric., Cairo. Univ., Egypt.

Page, A.L.; R.H. Miller and D. R. Keeney (1982). Method of Soil Analysis part 2. Amer. Sco. Agric. Inc. Madison.

Stevenson,F.J.1995. Humus Chemistry Genesis, Composition, Reaction. Jhon, wiley and Sons, INC.

Yanni.Y.G.1979. Some microbiological and physicochemical studies on waterlogging soils with special reference to the transformation of some soil elements. Ph.D. Thesis, Fac. of Agric., Ain-Shams Univ., Egypt.

Zein, F.I., Hegab, O.A. and El- Sanafawy, H.M. 1998. Geochemical studies on some polluted soil in Kafr El- Sheikh Governorate. Egypt.J.Agric. Sci. Mansoura Univ 23 (6), 2887.

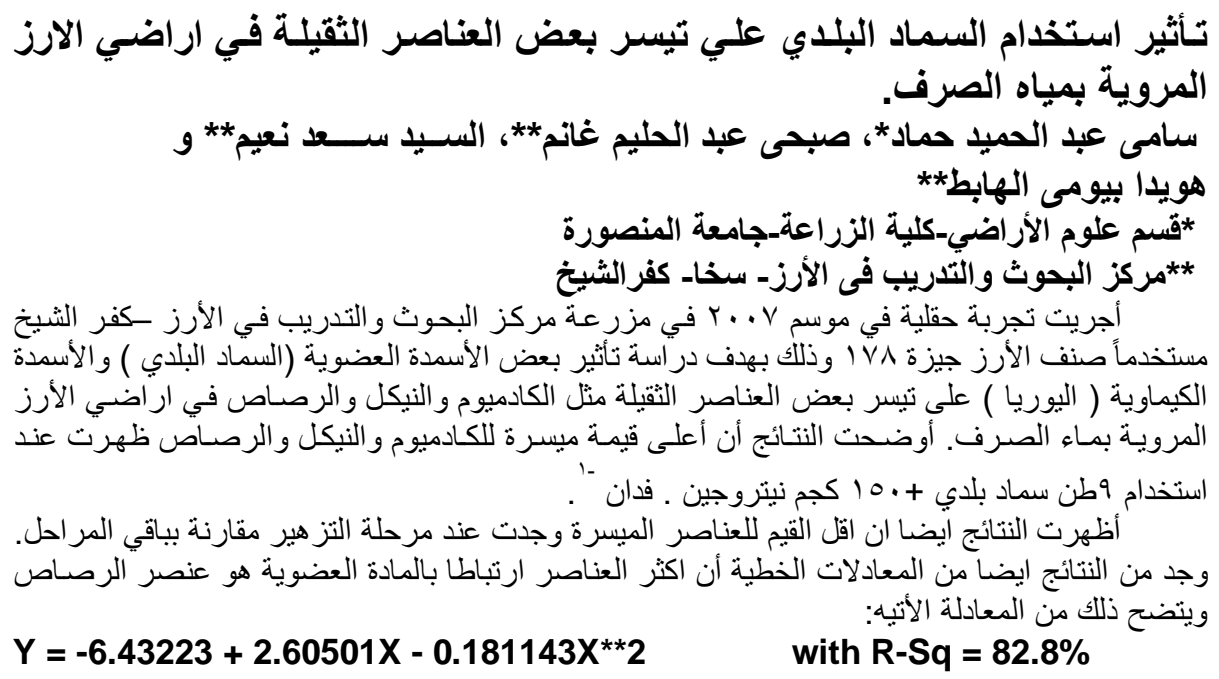

$\mathrm{Y}=$ organic matter

$\mathrm{X}=$ available lead 